\title{
Linkage of small-scale spatial variations in DOC, inorganic nutrients and bacterioplankton growth with different coral reef water types
}

\author{
Fleur C. van Duyl*, Gert Jan Gast \\ Netherlands Institute for Sea Research, PO Box 59, 1790 AB Den Burg, The Netherlands
}

\begin{abstract}
This study focuses on links of dissolved organic carbon (DOC), inorganic nutrients (DIN and DIP) and bacterioplankton growth with specific coral reef water types. At 5 reef stations along the SW coast of Curaçao (Netherlands Antilles), 6 different water types (4 reef water types [live coral surface contact water, reef crevice water, reef bottom water, reef overlying water] and 2 reference water types collected offshore from each station at 2 and $8 \mathrm{~m}$ depth) were analysed for DOC, DIN and DIP, bacterial production and abundance. Consistent patterns were found: reef waters were enhanced in DIN, DIP and specific bacterial growth rate $\left(\mu_{n}\right)$ compared to offshore waters. DOC, DIP, and $\mu_{n}$ were higher close to the reef bottom than in the reef overlying water. Coral surface contact water was significantly enhanced in DOC compared to reef crevice and reef bottom water, suggesting that the major source of DOC in reef waters are the live corals. DIN concentration was highest in reef crevice water, suggesting that crevices are the major net N-regenerating spaces on reefs, more important than the reef bottom between corals. Small-scale DIP distribution suggested net P regeneration in reef crevice and coral surface contact water. The highest specific growth rates of bacterioplankton were found in the coral surface contact water, with slightly lower rates in reef crevice water. Experiments showed that the labile DOC fraction (LDOC) in reef crevice water was substantially smaller than in coral surface contact and reef overlying water, which suggests that crevices are apparently sinks of LDOC. In reef crevice and reef bottom water the low substrate LDOC:DIN ratios suggest that LDOC might be the growth-limiting factor of bacterioplankton in these water types. In coral surface contact and reef overlying water the substrate LDOC:DIN ratios of more than 40 (and LDOC:DIP ratios of over 800) and the significant relations between $\mu_{n}$ and DIN (DIP) suggest nutrient limitation of bacterioplankton growth in these water types. This study clearly illustrates the close link in reef waters between coral reef benthos and bacterioplankton trophodynamics.
\end{abstract}

KEY WORDS: Coral reef $\cdot$ Bacterioplankton growth $\cdot$ DOC $\cdot$ DIN $\cdot$ DIP

Resale or republication not permitted without written consent of the publisher

\section{INTRODUCTION}

Coral reefs are characterised by relatively high gross primary productivity sustained by the symbiosis between corals and symbiotic algae, the large photosynthetically active area of reef surfaces, ample light, and inorganic carbon (e.g. Hinde 1988). Moreover, coral reefs are well known to trap particulate organic matter and nutrients from the overlying water (e.g. Glynn

*E-mail: duyl@nioz.nl
1973, Ayukai 1995, Thomas \& Atkinson 1997, Yahel et al. 1998). Nevertheless, the gross respiratory consumption in reef systems is approximately equal to the gross photosynthetic fixation, and the net flux of organic matter is typically small (Kinsey 1985). This implies a rapid mineralization of organic matter. Little is known about the small-scale spatial distribution of production and decomposition processes on reefs. Our knowledge is particularly limited with respect to microbial decomposition of organic matter in reef waters (Ducklow 1990, Hatcher 1997). 
It has been recognised that in coral reef waters a flux of dissolved and particulate material emanates from benthic algae and corals and from the underlying sediment (Ducklow 1990). Dissolved organic matter accumulates over coral reefs and in lagoons compared to adjacent oceanic surface waters (Hatcher 1983, Ducklow 1990, Torréton et al. 1997), indicating that in reef waters the production of dissolved organic carbon (DOC) exceeds the loss. Part of the gross primary production of corals is released as mucus, DOC, and DON (e.g. Richman et al. 1975, Crossland et al. 1980, Hatcher 1983, Crossland 1987, Ferrier-Pagès et al. 1998). In regenerative spaces in the reef matrix, nutrients are returned to the water phase (Di Salvo \& Louis 1971, Hatcher 1997). Benthic suspension feeders, microbial activity in coral skeletons and sediments have been identified as sources for dissolved inorganic nutrients (DIN and DIP) on reefs (Risk \& Müller 1983, Moriarty et al. 1985a, Corredor et al. 1988). Under oligotrophic conditions DIN, particularly $\mathrm{NH}_{4}{ }^{+}$, and DIP, as $\mathrm{Pi}$, mainly provide in the $\mathrm{N}$ and $\mathrm{P}$ demands of heterotrophic bacteria (Kirchman 1994). This implies that key elements for the growth of auto- and heterotrophic planktonic microorganisms are fluxed from the reef into the overlying water.

In the mucus layer of stony corals, extremely active microbial communities have been found compared to ambient water (e.g. Paul et al. 1986, Wahbeh \& Mahasneh 1988). In live coral contact water, the hydrolysis of mucus compounds probably enhances the diffusion of DOC from the mucus layer and from suspended mucus flocs into the surrounding water. The primary consumers of DOC are heterotrophic bacteria which take up bioavailable organic matter. Not much is known about the degradable part of DOC in reef waters and its utilisation by bacterioplankton (Torréton et al. 1997), although we know that the total flux of C into bacterioplankton biomass is often enhanced in coral reef waters (Moriarty et al. 1985b, Gast et al. 1999). On the other hand, grazing on bacterioplankton by presumably benthic suspension feeders has been shown to reduce numbers substantially in coral reef waters compared to adjacent waters (Ayukai 1995, Gast et al. 1998). In this study the influence of the reef on the food conditions for bacterioplankton is analysed. As a tool we used the specific growth of bacteria. Specific growth rates of bacteria have been reported to be enhanced in reef waters and reef lagoons (Torréton et al. 1997, Ferrier-Pagès \& Gattuso 1998).

We focused on small-scale spatial distribution of bacterial growth in the reef matrix to allocate the main sources (and sinks) of bacterial food requirements. DOC concentrations, inorganic nutrient concentrations, heterotrophic bacterial production, and abundance were measured in different coral reef water types. In addition, the bioavailable DOC pool and the growth yield of heterotrophic bacteria were tested experimentally in different water types. The aim of the present study is to get more insight into the linkage of reef benthos with bacterioplankton growth distribution patterns in coral reef waters. The study was initiated to increase our understanding of the role of heterotrophic bacterioplankton in energy pathways on coral reefs.

\section{MATERIAL AND METHODS}

Sampling. The small-scale spatial distribution of bacterial growth was studied in the field at 5 sampling stations on the fringing reefs along the leeward side of Curaçao, Netherlands Antilles, between 10 and 26 January 1995 (Fig. 1). The reefs have a 60 to $120 \mathrm{~m}$ wide reef terrace, which gradually slopes from the shoreline to the drop off at approximately $10 \mathrm{~m}$ depth (van Duyl 1985). Reef stations were located close to the drop off in 6 to $8 \mathrm{~m}$ deep water and with a coral cover of 10 to $40 \%$. At each station 4 different reef water types (coral surface water [CS], reef crevice water $[R C]$, reef-bottom water $[R B]$, reef overlying water at $2 \mathrm{~m}$ depth [RO]) and 2 reference water types (water off the reef break, drop off or blue edge at 2 [BE2] and at $8 \mathrm{~m}$ depth [BE8]) were collected. One station was visited per day, and at each station the water samples were usually taken in the morning between 09:00 and

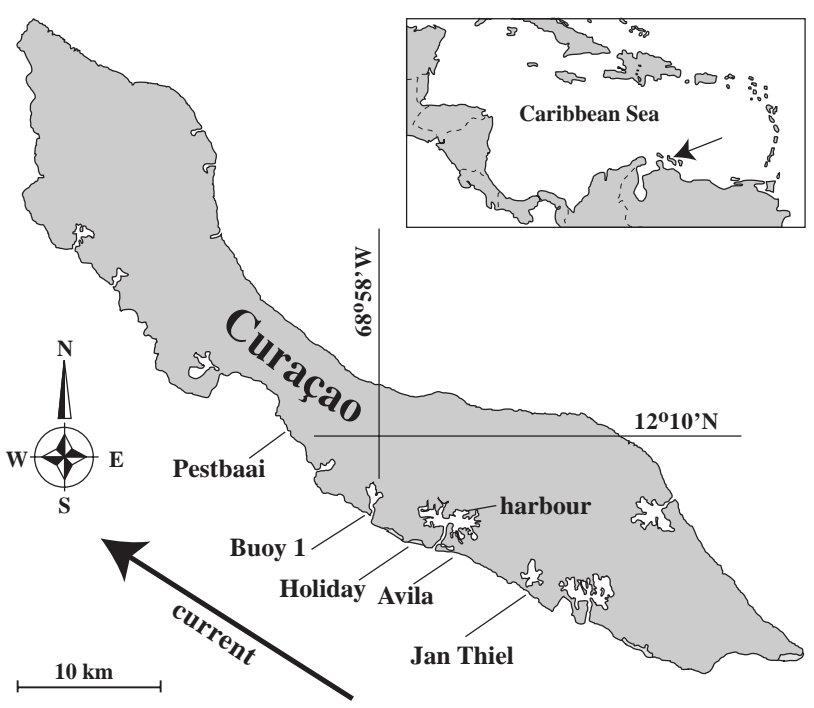

Fig. 1. Location of the 5 research stations along the SW coast of Curaçao, Netherlands Antilles, with an inset of the location of Curaçao in the Caribbean Sea. The large industrial harbour of Willemstad is indicated with its entrance between Stns Holiday and Avila. The residual current runs from SE to NW along the island 
10:30 h. The temporal distribution of bacterial growth was studied at one of the sampling stations: Buoy 1. This station was visited 5 times between 10 and 26 January 1995: 3 times in the morning between 09:00 and 10:30 $\mathrm{h}$, once in the afternoon and twice during the night after daytime sampling to assess diurnal variations (10/11 and 25/26 January).

Water samples from the CS were taken with $750 \mathrm{ml}$ syringes at 6 to $8 \mathrm{~m}$ depth while SCUBA diving. A syringe with a flexible tube was slowly and gently dragged over the coral surface of several colonies of Montastrea faveolata and Madracis mirabilis while withdrawing water from the coral surface. To fill a syringe approximately $2 \mathrm{~m}$ of coral surface was sampled, $1 \mathrm{~m}$ over $M$. faveolata and $1 \mathrm{~m}$ over $M$. mirabilis. $\mathrm{RC}$ was collected in small cavities or crevices with an estimated volume of less than 501 under live corals with a $750 \mathrm{ml}$ syringe. RB was collected between the sediment surface at 6 to $8 \mathrm{~m}$ depth and the highest (1 to $1.5 \mathrm{~m}$ ) coral colonies by a SCUBA diver using 51 Niskin bottles. At $2 \mathrm{~m}$ depth RO was collected with Niskin bottles from a dinghy anchored over the respective station. For duplicate measurements CS, RC and RB samples were collected in 2 water columns approximately $50 \mathrm{~m}$ apart. Duplicate RO samples were collected using the anchored dinghy at a 1 to $2 \mathrm{~h}$ interval. Just before the sampling of reef water types, water off the reef break, drop off or blue edge, was collected at 2 and $8 \mathrm{~m}$ depth (BE2 and BE8) as references for reef water.

Seawater dilution experiments were carried out to assess the bioavailable DOC pool and the growth yield of heterotrophic bacteria. For dilution cultures CS, RC and RO was collected at Stn Buoy 1 on 23 January between 10:30 and 12:30 h. The water was pre-filtered over GF/F and subsequently filtered over $0.22 \mu \mathrm{m}$ Millepore filters (gravity filtration). Six opaque $10 \mathrm{l}$ collapsible plastic containers with taps were acid-cleaned and rinsed with distilled water and filtered seawater. Then the containers were filled with 41 bacteria-free water, 2 with filtered CS, 2 with filtered RC and 2 with filtered RO. Subsequently 11 of grazer-free RO (gravity-filtered over $0.8 \mu \mathrm{m}$ filters) was added to all 6 containers. The incubation was conducted at in situ temperature $\left(27.2^{\circ} \mathrm{C}\right)$. At time zero the DOC fraction $<0.2 \mu \mathrm{m}$ was sampled in all 6 containers. At 4 subsequent sampling times bacterial production, abundance, and DOC were measured. Labile DOC (LDOC) refers to DOC consumed within $36 \mathrm{~h}$ in the seawater cultures.

Analyses. DOC of field samples was obtained by the gravity filtration of samples through a pre-combusted and seawater-washed GF/F filter. From each filtered water sample, 3 replicates of $5 \mathrm{ml}$ were transferred into pre-combusted glass ampoules, which were sealed immediately after the addition of potassium persulfate $\left(\mathrm{K}_{2} \mathrm{~S}_{2} \mathrm{O}_{8} ; 250 \mathrm{mg}\right.$ per ampoule with $5 \mathrm{ml}$ sample) and

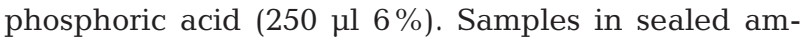
poules were autoclaved for $3 \mathrm{~h}$ at $120^{\circ} \mathrm{C}$. Subsequently the DOC concentration was measured with the wet chemical oxydation method (WCO), and measurements were corrected for chemical blanks (Menzel \& Vaccaro 1964). In an international intercalibration activity, our WCO method was compared with the high temperature combustion method (HTC), and differences in DOC concentrations of samples fell within the range of $\pm 10 \%$ (Sharp 1997, Wiebinga 1999).

For inorganic nutrient analyses 4 pony vials per water sample were filled with 4 to $5 \mathrm{ml}$ after filtration over seawater-washed $0.2 \mu \mathrm{m}$ Acrodisc filters, and were then stored frozen until analysis. Concentrations of DIN (DIN $=\mathrm{NH}_{4}+\mathrm{NO}_{3}+\mathrm{NO}_{2}$ ) and orthophosphate $\left(\mathrm{DIP}=\mathrm{PO}_{4}\right)$ were determined on a TRAACS 800 autoanalyzer (Technicon). $\mathrm{NH}_{4}$ was detected as indophenol blue complex at pH 10.5 at $630 \mathrm{~nm}$ (Helder \& de Vries 1979); $\mathrm{NO}_{3}$ was reduced in a copper cadmium coil to nitrite (using imidazole as a buffer) and measured as nitrite. $\mathrm{NO}_{2}$ was detected after diamide and $\mathrm{N}$-(1-naphthyl)-ethylene diammonium dichloride as the reddish purple dye complex at $540 \mathrm{~nm}$ (Grasshoff et al. 1999). Ortho-phosphate was measured by the formation of a blue-reduced molybdophosphate-complex at $\mathrm{pH}$ 0.9-1.1 with potassiumantimonyltartrate as catalyst and ascorbic acid as a reductant and measured at $880 \mathrm{~nm}$ (Murphy \& Riley 1962). Part of the nutrient data were already published in Gast et al. (1998).

Heterotrophic bacterial production (BP) was determined from incorporation rates of ${ }^{3} \mathrm{H}$-leucine (Dupont de Nemours, L-[3, 4, 5- $\left.{ }^{3} \mathrm{H}(\mathrm{N})\right]$ leucine, $143-168 \mathrm{Ci}$ $\mathrm{mmol}^{-1}$ ) into bacterial protein. Aliquots of seawater amended with $30 \mathrm{nM}$ leucine (10\% labelled, 90\% unlabelled) were incubated at field temperature for up to $1 \mathrm{~h}$, after which they were treated according to Simon \& Azam (1989). From each water sample 3 subsamples and 1 blank were amended with leucine. Blanks were fixed with buffered $0.2 \mu \mathrm{m}$ filtered formaldehyde (final concentration $0.7 \%$ ) before leucine addition. Bacterial production was expressed as the amount of cells produced per unit time. The conversion factor relating cell production to substrate was empirically determined for bacterial populations in $\mathrm{RO}$ water and was $7 \times 10^{16}$ cells mol $^{-1}$ leucine incorporated (Gast 1998).

Bacteria were counted with an epifluorescence microscope after staining with acridine orange and were then collected onto $0.2 \mu \mathrm{m}$ Sudan black pre-stained polycarbonate membrane filters (Poretics). The specific bacterial growth rate $\left(\mu_{n}\right)$ was determined by dividing the bacterial production (cells $\mathrm{l}^{-1} \mathrm{~h}^{-1}$ ) by the number of bacteria (cells $\mathrm{l}^{-1}$ ). 
Statistical analysis. All statistical analyses were done with SYSTAT 7.0 (Wilkinson 1997), using the general linear models (GLM) module. A randomized-block analysis of variance (ANOVA) with water type and block as independent variables was used to investigate the effect of water type on the variation of dependent variables, such as DOC, DIN, DIP, and $\mu_{n}$. Blocks consisted of unique combinations of station and day on which the respective station was sampled (e.g. Block 1: Stn Buoy 1, 10 January). A priori multiple comparisons were run to test for the differences between (groups of) specific water types. To distinguish station effect from time effect within blocks hierarchical tests were conducted, including station first and subsequently time. The least squares means of variables generated by the GLM were applied to demonstrate the best estimated differences in variables between water types after filtering for block effect.

\section{RESULTS}

\section{Temporal and spatial variability}

During the fieldwork weather conditions were stable with steady easterly trade winds, which picked up in the morning and died down in the evening. Water temperature varied between 27.2 and $27.8^{\circ} \mathrm{C}$, and there was no rain of importance (see also Gast et al. 1999).

Temporal variability during the day-night cycle was not observed. No consistent variations in DIN, DIP, inorganic $\mathrm{N}: \mathrm{P}$ ratio, and $\mu_{\mathrm{n}}$ between day- and nighttime sampling at Buoy 1 (Fig. 2b-d) was found. DIN slightly increased and $\mu_{\mathrm{n}}$ slightly decreased in RB at night. Lower values of DOC were found in reef water types at night rather than during daytime (Fig. 2a, ANOVA $n=8, p<0.05$ ), but the comparison was only made once. The diurnal data set was thus limited, and the effects of different water types could not be tested (too few data).

Temporal variability over the period of sampling also appeared to be low. The measurements at Buoy 1 (Fig. 2, Fig. 3: 14 January) revealed that the water mass characteristics did not substantially change between 10 and 26 January. Only the DOC concentrations tended to drop temporally. This aspect is reflected in the analyses of the general linear model of all data (Table 1) depicted in Figs. 2 \& 3, which show that time (as part of the block) played a significant role in the variations of DOC and DIN:DIP ratio.

With respect to spatial variability, apart from time, station location (as main part of the block) also played a significant role in the variations in DIN, DIP, DIN:DIP ratio and $\mu_{n}$ (Table 1 ). In Fig. $3 a-e$ differences in variables among 5 different stations and water types within stations are shown. Stn Holiday was enriched in DIN compared to the other stations, which also resulted in the higher DIN:DIP ratio at this station (Fig. 3d). Stns Holiday, Avila and Jan Thiel showed higher DIN and DIP concentrations in reef water types than the Stns Pestbaai and Buoy 1. Table 1 shows that time and station as represented in blocks accounted for 27 to $61 \%$ of the variation in variables (DOC $55 \%$, DIN $61 \%$, DIP $27 \%$, DIN:DIP ratio $61 \%, \mu_{n} 40 \%$ ) and that 17 to $40 \%$ of the variations were due to water type (DOC $17 \%$, DIN $17 \%$, DIP $32 \%$, DIN:DIP ratio $17 \%, \mu_{n} 40 \%$ ) (SS of water type, block and error together represent $100 \%$ for
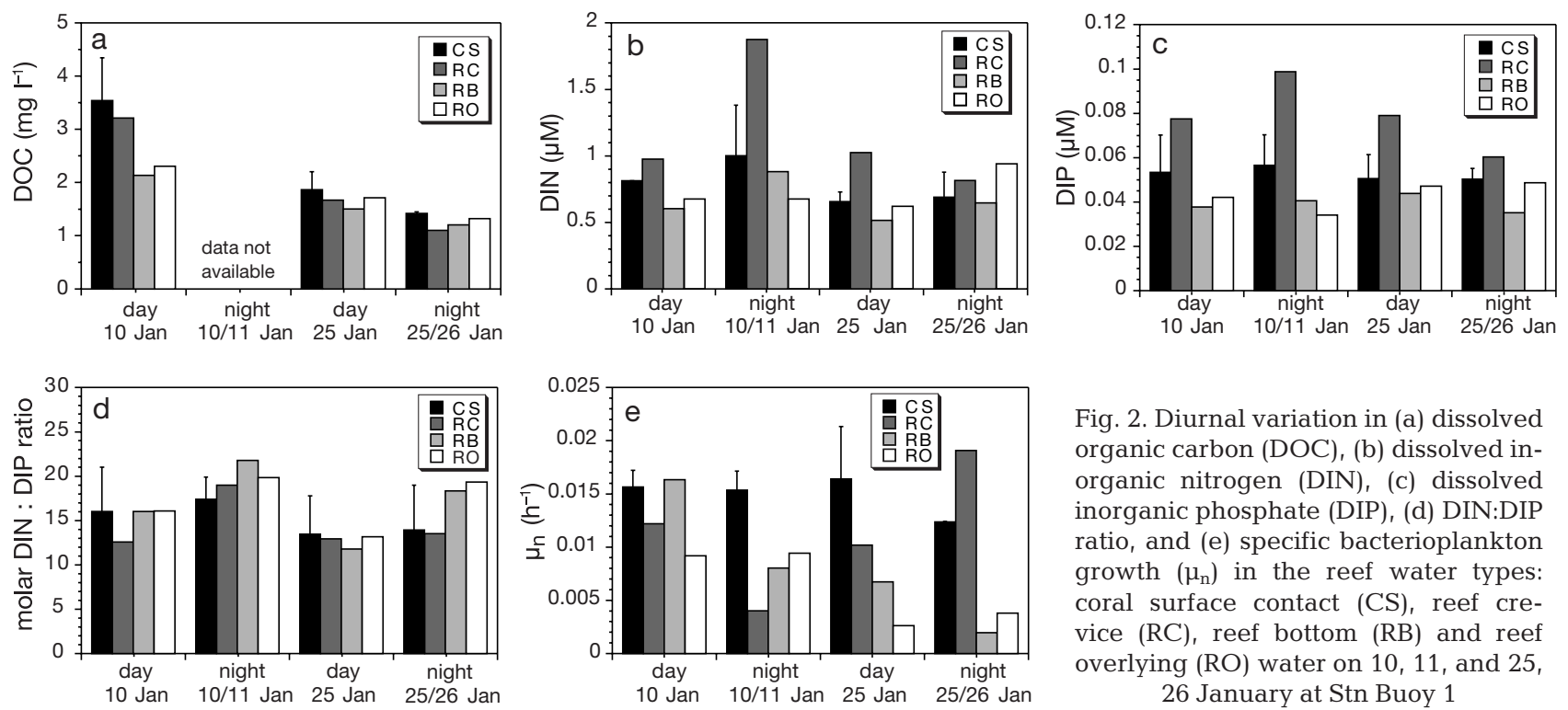

Fig. 2. Diurnal variation in (a) dissolved organic carbon (DOC), (b) dissolved inorganic nitrogen (DIN), (c) dissolved inorganic phosphate (DIP), (d) DIN:DIP ratio, and (e) specific bacterioplankton growth $\left(\mu_{n}\right)$ in the reef water types: coral surface contact (CS), reef crevice $(\mathrm{RC})$, reef bottom $(\mathrm{RB})$ and reef overlying (RO) water on 10,11, and 25, 26 January at Stn Buoy 1 

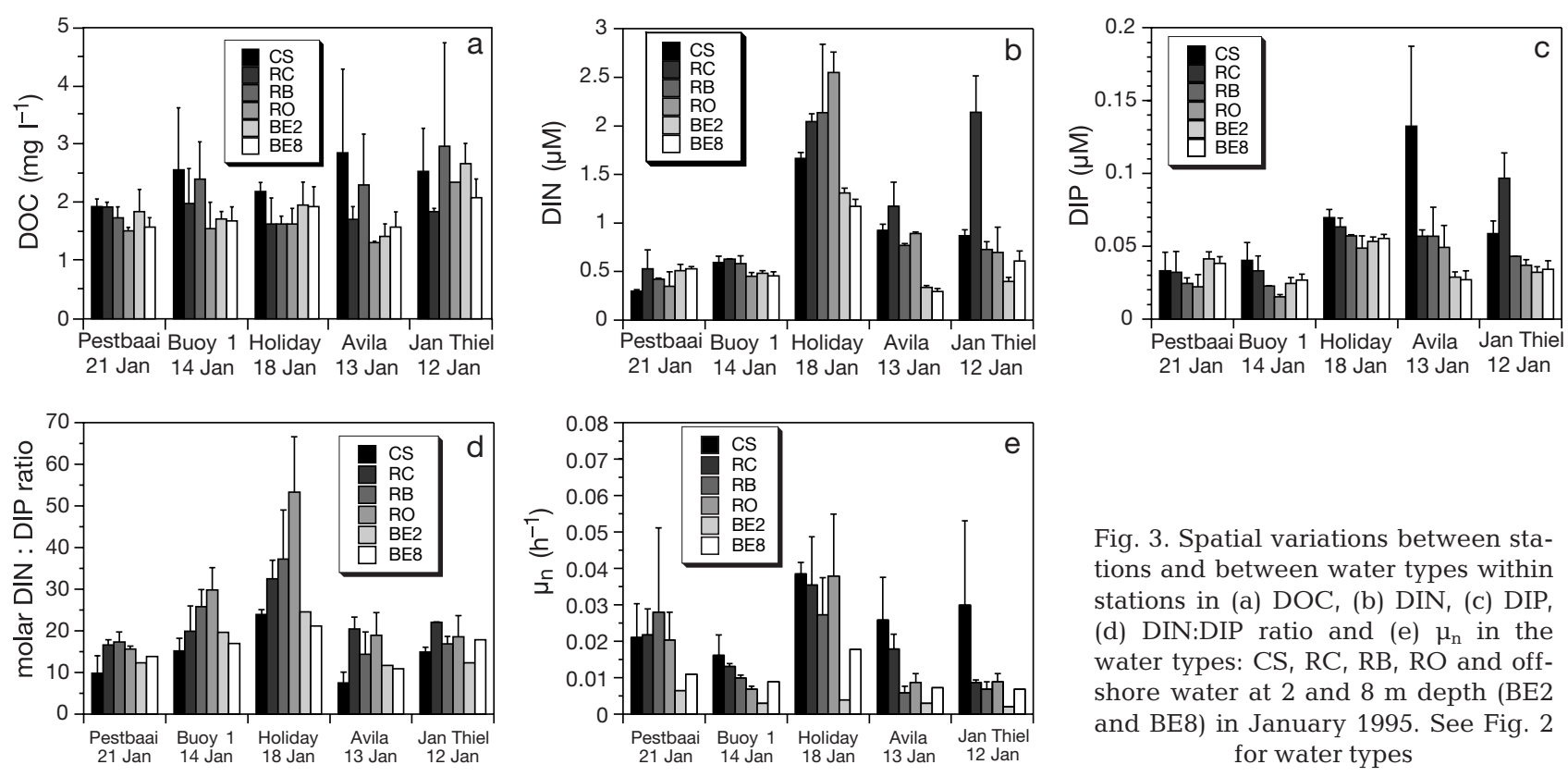

Fig. 3. Spatial variations between stations and between water types within stations in (a) DOC, (b) DIN, (c) DIP, (d) DIN:DIP ratio and (e) $\mu_{\mathrm{n}}$ in the water types: $\mathrm{CS}, \mathrm{RC}, \mathrm{RB}, \mathrm{RO}$ and offshore water at 2 and $8 \mathrm{~m}$ depth (BE2 and BE8) in January 1995. See Fig. 2 for water types

each variable). Apart from the spatial variability of variables between stations, Fig. 3 shows that variable patterns within different stations are often comparable and related to water types (see below).

\section{Water types}

At all stations, water type played an important role in the small-scale spatial distribution of variables and contributed significantly to the explanation of the variation in DOC, DIN, DIP, DIN:DIP ratio and $\mu_{\mathrm{n}}$ (Table 1). Reef water (CS, RC, RB, RO) was significantly different from offshore water (BE2 and BE8) with respect to DIN, DIP, DIN:DIP ratio and $\mu_{n}$ (Table 1$)$. These variables were enhanced in reef waters compared to offshore waters
(Fig. 4b,c,d,e). This was not found for the DOC variations (Fig. 4a, Table 1). Among reef water types DOC, DIP, DIN:DIP ratio and $\mu_{n}$ were significantly enhanced close to the bottom ( 6 to $8 \mathrm{~m}$ depth) compared to RO (2 m depth) (Table 1). Among CS, RC and RB types, DOC concentration in CS significantly differed from DOC in $\mathrm{RC}$, with the highest concentration in the CS (Fig. 4a). There was a trend of a decrease in DOC from the CS via $\mathrm{RB}$ and $\mathrm{RC}$ to the lowest DOC concentration in the RO (Fig. 4a, Table 1). In reef crevices the DIN concentration was significantly higher than in the CS and RB (Fig. 4b, Table 1). No significant differences between water types close to the reef bottom $(\mathrm{CS}, \mathrm{RC}, \mathrm{RB})$ and $\mathrm{RO}$ were found (Table 1). This was at least partly due to the enhanced DIN concentrations in RO at Stns Holiday and Avila (Fig. 3b). Among CS, RC, and RB types, DIP

Table 1. Summaries of the ANOVA due to water type and block (station, time) of variables DOC, DIN, DIP, DIN:DIP ratio and $\mu_{\mathrm{n}}$ (42 or 46 observations: 6 water types, 8 or 9 blocks) with a priori multiple comparisons of the effect of different water types (for abbreviations see text) on variables. ${ }^{* * *} \mathrm{p}<0.05,{ }^{*} \mathrm{p} \leq 0.1$ and $\geq 0.05, \mathrm{~ns}=$ not significant

\begin{tabular}{|c|c|c|c|c|c|c|c|c|c|c|c|c|c|c|c|c|c|c|c|c|}
\hline \multirow[t]{2}{*}{ Source } & \multicolumn{4}{|c|}{$-\mathrm{DOC}-$} & \multicolumn{4}{|c|}{$\longrightarrow$ DIN -} & \multicolumn{4}{|c|}{$\longrightarrow$ DIP -} & \multicolumn{4}{|c|}{ — DIN:DIP ratio - } & \multirow[b]{2}{*}{ df } & \multirow[b]{2}{*}{ SS } & \multicolumn{2}{|c|}{$\mu_{\mathrm{n}}$} \\
\hline & df & SS & F-ratio & $\mathrm{p}$ & df & SS & F-ratio & $\mathrm{p}$ & df & SS & F-ratio & $\mathrm{p}$ & df & SS & F-ratio & $\mathrm{p}$ & & & F-ratio & $\mathrm{p}$ \\
\hline Water type & 5 & 2.10 & 3.62 & * & 5 & 2.26 & 5.04 & **** & 5 & 0.007 & 4.57 & *** & 5 & 498 & 4.95 & **** & 5 & 0.002 & 11.20 & *** \\
\hline RO, CS, RC, RB vs BE2, BE8 & 1 & 0.23 & 1.96 & ns & 1 & 1.13 & 12.63 & $* * *$ & 1 & 0.001 & 4.16 & $*$ & 1 & 196 & 9.72 & $* * *$ & 1 & 0.001 & 35.30 & $* * *$ \\
\hline $\mathrm{RO}$ vs $\mathrm{CS}, \mathrm{RC}, \mathrm{RB}$ & 1 & 0.79 & 6.85 & $* * *$ & 1 & 0.06 & 0.62 & ns & 1 & 0.002 & 7.07 & *** & 1 & 163 & 8.10 & $* * *$ & 1 & $<0.0005$ & 54.52 & $* * *$ \\
\hline CS vs RC & 1 & 0.92 & 7.96 & $* * *$ & 1 & 0.76 & 8.43 & $* * *$ & 1 & $<0.0005$ & 0.51 & ns & 1 & 78 & 3.89 & $*$ & 1 & $<0.0005$ & $5 \quad 4.52$ & $* * *$ \\
\hline $\mathrm{CS}, \mathrm{RC}$ vs RB & 1 & 0.10 & 0.86 & $\mathrm{~ns}$ & 1 & 0.32 & 3.55 & $*$ & 1 & 0.003 & 11.10 & *** & 1 & 61 & 3.04 & * & 1 & $<0.0005$ & $5 \quad 7.73$ & *** \\
\hline BE2 vs BE8 & 1 & 0.06 & 0.48 & ns & $1<$ & $<0.0005$ & 50.001 & ns & 1 & $<0.0005$ & $<0.0005$ & ns & 1 & 0.002 & $<0.0005$ & ns & 1 & $<0.0005$ & $5 \quad 3.92$ & ${ }^{*}$ \\
\hline Block & 7 & 6.75 & 8.33 & $* * *$ & 8 & 7.95 & 11.07 & $* * *$ & 8 & 0.006 & 2.37 & *** & 8 & 1725 & 10.72 & $* * *$ & 8 & 0.002 & 8.82 & $* * *$ \\
\hline Station & 4 & 1.65 & 1.57 & ns & 4 & 7.43 & 19.71 & $* * *$ & 4 & 0.003 & 2.68 & $* * *$ & 4 & 1430 & 13.71 & $* * *$ & 4 & 0.002 & 16.87 & *** \\
\hline Time & 3 & 5.09 & 14.68 & $* * *$ & 4 & 0.52 & 1.45 & ns & 4 & 0.003 & 1.81 & ns & 4 & 295 & 3.67 & $* * *$ & 4 & 0.000 & 0.92 & ns \\
\hline Error & 29 & 3.36 & & & 32 & 2.87 & & & 32 & 0.009 & & & 32 & 644 & & & 32 & 0.001 & & \\
\hline
\end{tabular}



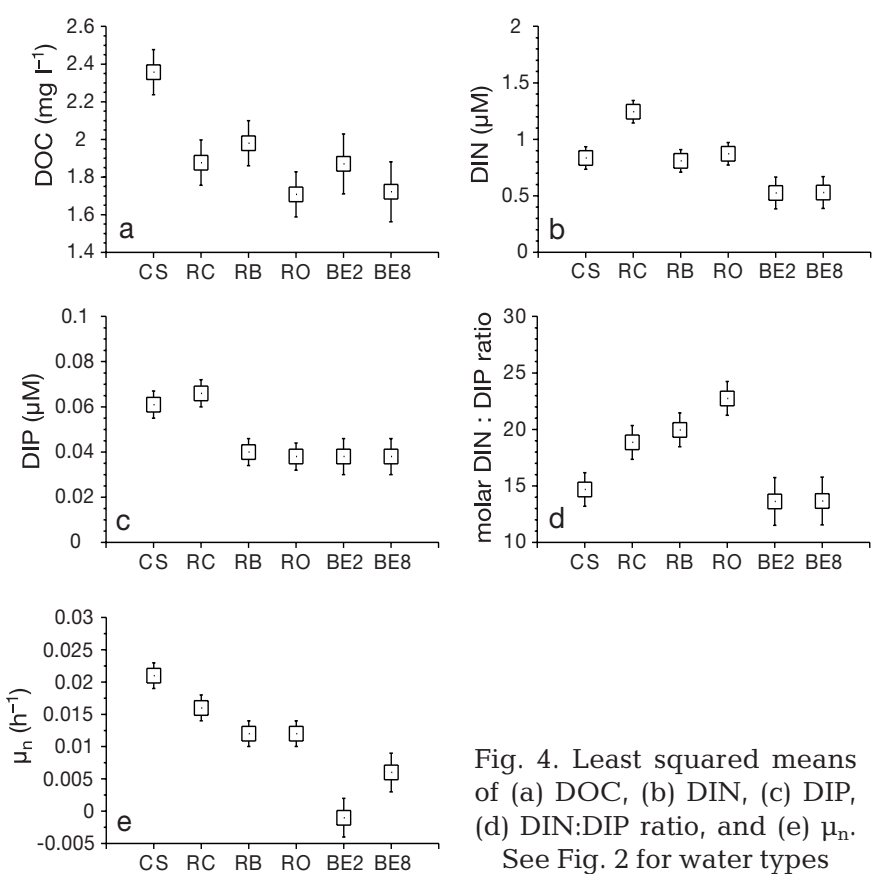

Fig. 4. Least squared means of (a) DOC, (b) DIN, (c) DIP, (d) DIN:DIP ratio, and (e) $\mu_{n}$. See Fig. 2 for water types concentration was significantly lower in RB than in CS and RC. DIP concentrations in CS and RC were not significantly different (Table 1, Fig. 4c). The DIN:DIP ratio showed greater differences between reef and offshore waters, and between RO (grouped CS, RC and RB types) than between $\mathrm{CS}, \mathrm{RC}$ and RB types (Table 1, Fig. 4d). The molar DIN:DIP ratio was occasionally below the Redfield ratio of 16 (Figs. $2 d \& 3 d$ ). Lowest ratios (lower limit of 8) were found in the CS and BE at Stn Avila and the highest ratios in the RO at Stn Holiday (Fig. 3d). $\mu_{n}$ was significantly enhanced in CS compared to RC and also in CS and RC compared to RB (Table 1). It is evident that the $\mu_{\mathrm{n}}$ decreased with distance from the reef, with lowest rates in the BE2 water (Fig. 4e). The BE2 and BE8 water did not show significant differences with respect to DOC, DIN, DIP and DIN:DIP ratio. Only the $\mu_{\mathrm{n}}$ was enhanced in BE8 compared to BE2 water (Table 1, Fig. 4e).

In the seawater dilution experiments, the initial DOC concentrations fell in the same range as the field concentrations of DOC. In all cultures DOC concentrations dropped to lower levels within 10 to $25 \mathrm{~h}$ (Fig. 5a). The decrease was most pronounced in CS (on average $30 \%$ or $756 \mu \mathrm{g} \mathrm{C}^{-1}$ ). The decline was smallest in $\mathrm{RC}$ (on average $14 \%$ or $256 \mu \mathrm{g} \mathrm{Cl}^{-1}$ ). DOC removal in RO was

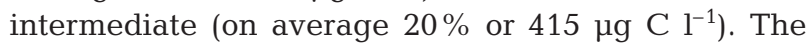
increases in DOC after $36 \mathrm{~h}$ of incubation roughly coincided with stabilisation of bacterial numbers (Fig. 5b). The highest abundance of bacteria was reached in the $\mathrm{CS}$ and the lowest abundance in $\mathrm{RC}$ after $36 \mathrm{~h}$ of incu- bation. The gross growth efficiency (GGE) of bacteria over this period was $7 \%$ in $\mathrm{CS}, 8 \%$ in $\mathrm{RO}$ and $12 \%$ in $\mathrm{RC}$, assuming a carbon content of $20 \mathrm{fg} \mathrm{C}^{\mathrm{C}} \mathrm{cell}^{-1}$ (Lee \& Fuhrman 1987). These GGEs were obtained by dividing the increase of bacterial biomass $(\times 100)$ by the DOC decrease in $36 \mathrm{~h}$ in the respective water types. Bacterial production sharply increased during the first $11.5 \mathrm{~h}$ and reached its highest level of activity within $25 \mathrm{~h}$ of the incubation (Fig. 5c). Increase rates were highest in the CS and lowest in the RC and the plateaus reached in the different water types were dif-
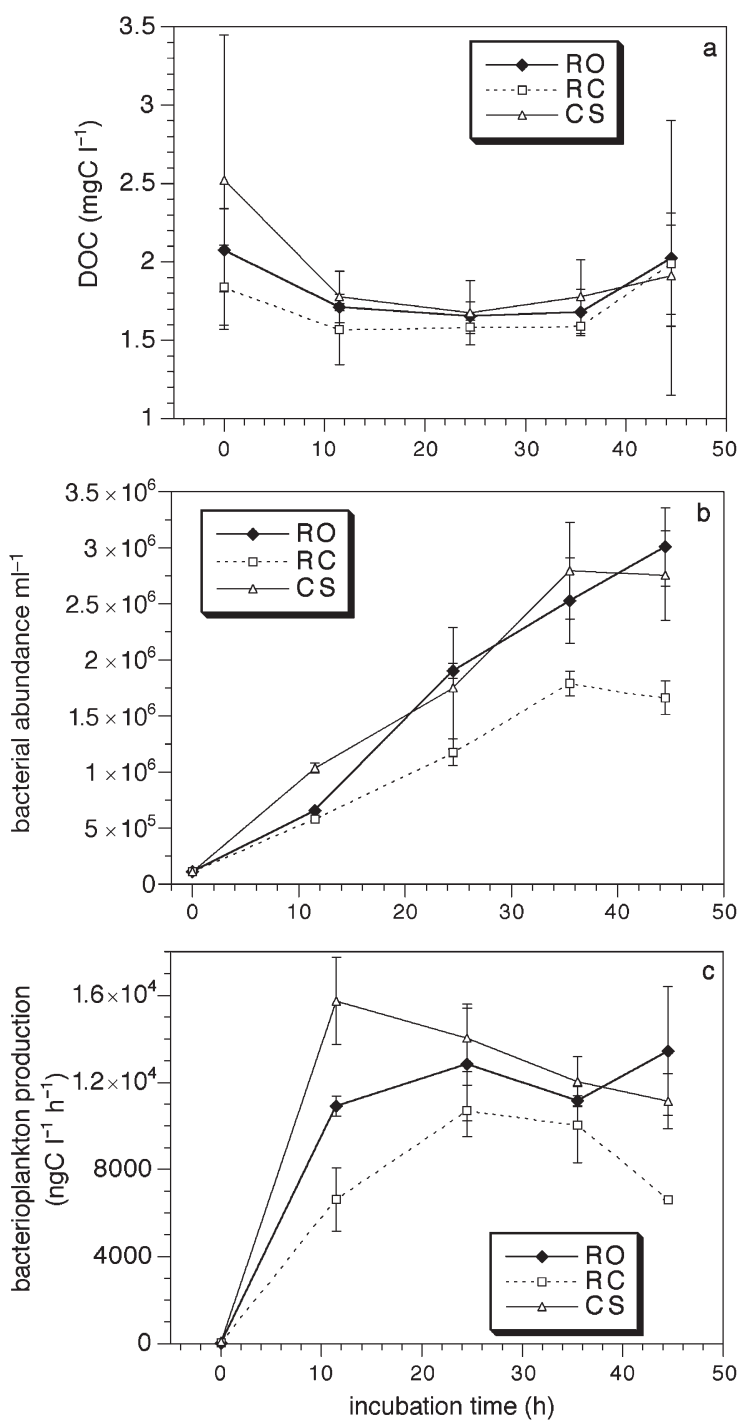

Fig. 5. Changes (a) in $0.2 \mu \mathrm{m}$ filtered DOC, (b) bacterial abundance and (c) bacterial production in $0.2 \mu \mathrm{m}$ filtered $\mathrm{RO}, \mathrm{RC}$ and CS water types during seawater incubation experiments. See Fig. 2 for water type. Data represent average values of 2 replicate incubations with standard deviations. The initial value of bacterial abundance is $1.13 \times 10^{5} \mathrm{ml}^{-1}$ and of bacterial production $18.6 \mathrm{ng} \mathrm{C}^{-1} \mathrm{~h}^{-1}$ 
ferent, the lowest for $\mathrm{RC}$ and the highest for CS. The decrease in DOC coincided with the increase in bacterial production, suggesting a rapid uptake of LDOC. It was evident that the yield in $\mathrm{CS}$ and RO exceeded the yield in $\mathrm{RC}$.

In Table 2 the substrate LDOC:DIN and LDOC:DIP ratios are presented in which the LDOC concentration is a fixed fraction of the total DOC concentrationin the field depending on water type. Applied fractions were derived from the incubation experiments. The LDOC fraction in RB, BE2 and BE8 was assumed to be comparable to the measured LDOC in RC (14\% of total DOC). LDOC:DIN ratios vary from 23 to 85 and LDOC:DIP from 400 to 1063 . The LDOC turnover by bacterioplankton (bacterial production divided by LDOC $\times$ GGE) ranged from $0.10 \mathrm{~d}^{-1}$ in CS and BE2 to $0.22 \mathrm{~d}^{-1}$ in $\mathrm{RC}$. We used a GGE of $10 \%$, which is the average value of GGEs found in the experiments (see above). The absolute LDOC concentrations in the experiments may have been underestimated, since no nutrient amendments were applied to the seawater cultures.

\section{Factors accounting for variations in bacterioplankton growth}

In $\mathrm{CS}, \mathrm{RO}$ and BE8 water respectively, relationships between $\mu_{n}$ and DIN were positive and significant (ANOVA: $\mathrm{n}=9$, adjusted $\mathrm{R}^{2}=0.40, \mathrm{p}<0.05 ; \mathrm{n}=9$, adjusted $\mathrm{R}^{2}=0.56, \mathrm{p}<0.05 ; \mathrm{n}=5$, adjusted $\mathrm{R}^{2}=0.76$, $\mathrm{p}<0.05)$. By adding the DIP concentration as second independent to the regression, the fit between $\mu_{n}$ and nutrients in RO improved, now explaining $73 \%$ of the variation $\left(n=9\right.$, adjusted $\left.R^{2}=0.73, p<0.05\right)$ with a positive relation to DIN and a negative relation to DIP. Moreover there was a significant positive relation in BE8 water between $\mu_{n}$ and DIP $\left(n=5\right.$, adjusted $\mathrm{R}^{2}=$ 0.82, $\mathrm{p}<0.05$ ). Significant relations between $\mu_{\mathrm{n}}$, DIN, and DIP were not found in $\mathrm{RC}, \mathrm{RB}$, and BE2 water. Variations in DOC did not significantly contribute to the explanation of the variations in $\mu_{n}$.

\section{DISCUSSION}

\section{Temporal and spatial variability}

The sampling design applied in this study automatically introduced a potential component of temporal variability of days, in addition to the spatial variability due to the distance between stations. Although diel rhythms influencing the release of mucus and DOClipids (Crossland 1987, Ferrier-Pagès et al. 1998, 2000), and nutrient fluxes (Johannes et al. 1983) have been found in coral reef waters, our variables did not show such a consistent light-dependent diurnal pattern. Diurnal variations in our studies may have been masked by dilution of CS with ambient water flowing over the reef and/or the chosen time intervals may have been unsuited to record diurnal changes. In addition, on long time scales (weeks), changes in water mass characteristics could not be established. This implies that the observed temporal changes in variables (such as the drop in DOC at Buoy 1, which was not reflected by a drop in other measured variables), and the differences in variables between stations were most likely not due to changes in water mass characteristics passing the island. The results suggest that differences in variables in time and between stations were generated by local factors.

Part of the spatial variability between stations could be explained by differences in local conditions. Especially the variations in run-off and drainage of polluted water from the coast probably played a role in the differences in magnitudes of variables among stations. DIN and $\mu_{n}$ were enhanced at Stn Holiday compared to the other stations. This was most likely due to the vicinity of this station to the harbour outlet. Gast et al. (1999) showed a gradient in DIN in front of Willemstad, Curaçao, with increased DIN concentrations downcurrent of the harbour entrance. DIN (DIP) and $\mu_{n}$ in reef water types at Stns Avila and Jan Thiel were slightly enhanced compared to values at Buoy 1 and Pestbaai. At Avila, strongly fluctuating and enhanced DIN and

Table 2. Overview of mean LDOC:DIN and LDOC:DIP ratios and LDOC turnover rates with standard deviations (SD) in different water types (see text for abbreviations) calculated for the field samples with LDOC \% of the DOC pool deduced from incubation experiments (see text)

\begin{tabular}{|c|c|c|c|c|c|c|c|c|c|c|}
\hline $\begin{array}{l}\text { Water } \\
\text { type }\end{array}$ & $\begin{array}{l}\text { LDOC as \% } \\
\text { of total DOC }\end{array}$ & $\mathrm{n}$ & $\begin{array}{c}\text { LDOC:DIN } \\
\text { ratio }\end{array}$ & $\mathrm{SD}$ & $\begin{array}{l}\text { LDOC:DIP } \\
\text { ratio }\end{array}$ & $\mathrm{SD}$ & $\begin{array}{c}\text { LDOC } \\
\text { turnover }\left(\mathrm{d}^{-1}\right)\end{array}$ & $\mathrm{SD}$ & $\begin{array}{c}\text { DOC } \\
\text { turnover }\left(\mathrm{d}^{-1}\right)\end{array}$ & $\mathrm{SD}$ \\
\hline CS & 30 & 8 & 85 & 39 & 1063 & 484 & 0.10 & 0.03 & 0.031 & 0.007 \\
\hline $\mathrm{RC}$ & 14 & 8 & 23 & 14 & 428 & 215 & 0.22 & 0.13 & 0.031 & 0.019 \\
\hline $\mathrm{RB}$ & 14 & 8 & 36 & 15 & 686 & 330 & 0.17 & 0.14 & 0.025 & 0.020 \\
\hline RO & 20 & 8 & 43 & 21 & 855 & 426 & 0.13 & 0.08 & 0.026 & 0.017 \\
\hline BE2 & 14 & 5 & 45 & 23 & 704 & 238 & 0.10 & 0.09 & 0.014 & 0.013 \\
\hline BE8 & 14 & 5 & 40 & 17 & 643 & 159 & 0.18 & 0.05 & 0.025 & 0.007 \\
\hline
\end{tabular}


DIP concentrations year-round have been described by Gast et al. (1999) (= town reef in their study). Both Avila and Jan Thiel stations are situated only 40 to $50 \mathrm{~m}$ from the coastline. This proximity to the coast may have contributed to the enhanced concentration of DIN (DIP) and $\mu_{n}$ in reef waters, although it did not appear to influence the small-scale spatial distribution of variables within these stations. Benthic mineralization may have been enhanced at these stations, particularly at Stn Jan Thiel, where a well-developed reef framework exists (van Duyl 1985, Gast et al. 1998). Unlike DIN, DIP and $\mu_{n}$, DOC concentrations did not significantly vary between stations. This suggests that local conditions with respect to run-off, discharge water, reef framework structure etc. appear to affect the variables DIN, DIP and $\mu_{\mathrm{n}}$ more than DOC.

\section{Water types}

At all stations, there were striking and consistent differences in DOC, DIN, DIP concentrations and $\mu_{n}$ between water types, distinguishing reef waters from offshore waters and RO from CS, RC and RB types close to the reef bottom. It should be noted that part of the differences in $\mu_{\mathrm{n}}$ in the surface water at $2 \mathrm{~m}$ and water at 6 to $8 \mathrm{~m}$ depth may be due to solar radiation. Visser et al. (1999, unpubl.) showed that solar radiation, in particular UV-A radiation at Curaçao, may inhibit heterotrophic BP to a depth of ca $5 \mathrm{~m}$ depth without affecting the total number of bacteria. Most of our samples, however, were taken in the morning when growth inhibition due to solar radiation is purported to be still low. It is possible that the growth difference between BE2 and BE8 water may have been due to solar radiation.

Variables in reef water types showed larger variations than variables in offshore water types off the reef slope. The vicinity of the reef bottom and reef benthos apparently plays a crucial role in the differentiation of reef water characteristics. The highest bacterioplankton growth rates were found in the CS. This may be related to coral exudates which have been shown to stimulate bacterioplankton growth in experimental set-ups (Ferrier-Pagès et al. 2000). The reason for the enhancement of growth in crevice water is less clear (see also Gast et al. 1998). The small-scale spatial variation in growth, with growth rates in $\mathrm{RB}$, which were significantly lower than in $\mathrm{CS}$ and $\mathrm{RC}$, suggest that coral exudates are not inducing the growth enhancement in crevices. The stimulation of bacterioplankton growth in crevices may be induced by exudates released in crevices. Growth rates in $\mathrm{RB}$ and $\mathrm{RO}$ were comparable. That these rates were higher than in offshore waters is clearly related to the vicinity of the reef.
The highest DOC concentrations of all reef water types were found in the CS. Live coral is apparently the main source of DOC in the reef structure. It is well known that corals allocate $50 \%$ of the gross primary production into mucus (e.g. Richman et al. 1975, Crossland et al. 1980, Hatcher 1983, Crossland 1987). DOC apparently emanated from the mucus layer of corals into the CS and ambient water. DOC concentrations significantly dropped from the CS towards the RB, RC and RO. This pattern may be due to dilution with ambient water with lower DOC concentrations and/or to bacterial consumption of DOC. The enhanced bacterial DOC turnover in CS compared to DOC turnover in $\mathrm{RB}, \mathrm{RO}$ and offshore water types suggest that bacterial consumption may have contributed to the observed DOC gradients.

The experiments with seawater cultures showed that LDOC (in \% of total DOC) decreases with distance from the live coral heads. The $30 \%$ LDOC in the CS drops to $20 \%$ in the RO and to $14 \%$ in the RC. The remarkable drop in DOC as well as in LDOC from CS to RC illustrates the strong gradients, which can occur in the DOC pool in coral reefs. RC is depleted in total DOC as well as LDOC compared to ambient reef water and RO. Benthic suspension feeders covering up to $60 \%$ of the hard substratum in crevices in Curaçao (Scheffers et al. unpubl.) may consume considerable amounts of DOC (Gili \& Coma 1998 and references therein). Nevertheless, specific growth rates of bacteria in $\mathrm{RC}$ were only slightly lower than the $\mu_{n}$ in CS. In CS, however, DIN was depleted compared to its concentration in RC. Assuming that dissolved organic $\mathrm{N}$ is not an important source of $\mathrm{N}$ in reef waters and that only stoichiometric quantities of DIN are utilized by bacteria (Goldman et al. 1987, Goldman \& Dennett 2000), we consider growth rates at substrate LDOC:DIN ratios of 40 or more as potentially limited by $\mathrm{N}$ and less than 40 potentially limited by LDOC based on our measured mean GGE on LDOC of $10 \%$ and a molar C:N ratio of bacterial biomass of 4 to 5 (Kirchman 1994). This implies that the substrate LDOC:DIN ratios in CS and RO $(\geq 40)$ may indicate that bacterial growth is N-limited. Significant positive relations between $\mu_{n}$ and DIN may also point in that direction. However, P-limitation of the $\mu_{n}$ cannot be excluded considering the low DIP concentrations (min. $0.02 \mu \mathrm{M})$, substrate LDOC:DIP ratios exceeding 700 in $\mathrm{CS}$ and RO (range in molar C:P ratios in bacterial biomass is 7 to 75) and relations between $\mu_{n}$ and DIP in RO and offshore water at $8 \mathrm{~m}$ depth. $\mathrm{PO}_{4}$-limited bacterioplankton growth have been reported for the Sargasso Sea and the Gulf Stream (Cotner et al. 1997, Rivkin \& Anderson 1997). These results and the relatively slow LDOC turnover rates in CS, RO and offshore water at $2 \mathrm{~m}$ depth (8 to $10 \mathrm{~d}$ ) suggest that LDOC may not be fully exploited in CS, RO and offshore waters. 
In RC with substrate LDOC:DIN ratios below 40, substrate LDOC:DIP ratios below 700 and DIN concentrations significantly higher than in CS and RB, nutrient limitation of bacterial growth is unlikely. Crevices might well be the most important net nutrient-regenerating spaces on reefs, which may partly be attributed to crevice-encrusting benthos, such as sponges known to excrete nitrate (Corredor et al. 1988). In conjunction it is reasonable to assume that bacterioplankton growth in RC is C-limited, which might also be the case in RB. LDOC turnover by bacterioplankton in these water types appears also to be faster ( 5 to $6 \mathrm{~d}$ ) than in the other reef water types, even without involving the purported LDOC loss to higher organisms in crevices. Our DOC turnover rates of 0.014 to $0.031 \mathrm{~d}^{-1}$ were generally slower than turnover rates measured in coral lagoons (Torréton et al. 1997, Torréton 1999), but this may have been due to the different bacterial growth efficiency applied (6.6 vs our 10\%) and bacterial production and biomass conversion factors.

It is obvious that the best conditions for bacterioplankton growth prevail in the CS with rapid nutrient regeneration and an ample supply of LDOC. That the DIP concentrations in CS and RC were significantly higher than in $\mathrm{RB}$ and $\mathrm{RO}$ suggests that both these water types are important sites of nutrient regeneration. Only in CS may regenerated $\mathrm{N}$ be immediately re-used by zooxanthellae in live corals (e.g. Muscatine et al. 1989) and bacteria, while in crevice water there appears to be excess production of both DIN and DIP. Preliminary results suggest that growth-limiting factors for bacterioplankton in CS and RC may differ. This would be remarkable considering the small distance of less than $1 \mathrm{~m}$ between these water types at the reef bottom. Different growth limitations on these scales may contribute to efficient cycling of nutrients within the living coral reef framework.

\section{CONCLUSIONS}

Observed variations in $\mu_{n}$, DOC, DIN and DIP concentrations between different reef water types were closely linked to substratum surface types (live coral surface, crevices below corals, sandy reef bottom). Live corals are a net source of DOC, and are probably the main source for enhanced DOC concentrations in coral reef waters. Reef crevices are probably sinks of DOC and net sources of DIN and DIP, and are as such probably more important regenerative spaces in the reef matrix than sandy reef bottoms. Although we cannot be conclusive with regard to the controlling factors of specific growth rates of heterotrophic bacteria in reef waters, there are indications that the $\mu_{n}$ in the reef water types is controlled differently. Bacterioplankton growth may be nutrient-limited in CS and RO and C-limited in RC and possibly also in RB. We clearly demonstrated small-scale spatial differences in bacterioplankton trophodynamics, closely linked to reef bottom characteristics.

Acknowledgements. The staff of Carmabi is gratefully acknowledged for their hospitality and logistic support during the fieldwork, with special thanks to Oscar Franz and Frank Isabella. We are grateful to Rolf Bak for collecting underwater samples and for stimulating discussions. Jan Hegeman is thanked for his contribution to the fieldwork and the DOC analyses. Jaap van der Meer is acknowledged for statistical advice. This is NIOZ publication 3556.

\section{LITERATURE CITED}

Ayukai T (1995) Retention of phytoplankton and planktonic microbes on coral reefs within the Great Barrier Reef, Australia. Coral Reefs 14:141-147

Corredor JE, Wilkinson CR, Vincente VP, Morell JM, Otero O (1988) Nitrate release by Caribbean reef sponges. Limnol Oceanogr 33:114-120

Cotner JB, Ammerman JW, Peele ER, Bentzen E (1997) Phosphorus-limited bacterioplankton growth in the Sargasso Sea. Aquat Microb Ecol 13:141-149

Crossland CJ (1987) In situ release of mucus and DOC-lipid from the corals Acropora variabilis and Stylophora pistillata in different light regimes. Coral Reefs 6:35-42

Crossland CJ, Barnes D, Borowitzka MA (1980) Diurnal lipid and mucus production in the staghorn coral Acropora acuminata. Mar Biol 60:81-90

DiSalvo LH, Louis H (1971) Regenerative functions and microbial ecology of coral reefs: labelled bacteria in a coral reef microcosm. J Exp Mar Biol Ecol 7:123-136

Ducklow HW (1990) The biomass, production and fate of bacteria in coral reefs. In: Dubinsky Z (ed) Ecosystems of the world: coral reefs, Vol 25. Elsevier, Amsterdam, p 265-289

Ferrier-Pagès C, Gattuso JP (1998) Biomass, production and grazing rates of pico-nanoplankton in coral reefs (Miyako Island, Japan). Microb Ecol 35:46-57

Ferrier-Pagès C, Gattuso JP, Cauwet G, Jaubert J, Allemand D (1998) Release of dissolved organic carbon and nitrogen by the zooxanthellate coral Galaxea fascicularis. Mar Ecol Prog Ser 172:265-274

Ferrier-Pagès C, Leclerq N, Jaubert J, Pelegrí SP (2000) Enhancement of pico- and nanoplankton growth by coral exudates. Aquat Microb Ecol 21:203-209

Gast GJ (1998) Microbial densities and dynamics in fringing coral reef waters. PhD thesis, University of Amsterdam

Gast GJ, Wiegman S, Wieringa E, van Duyl FC, Bak RPM (1998) Bacteria in coral reef water types: removal of cells, stimulation of growth and mineralization. Mar Ecol Prog Ser 167:37-45

Gast GJ, Jonkers PJ, van Duyl FC, Bak RPM (1999) Bacteria, flagellates and nutrients in island fringing coral reef waters: influence of the ocean, the reef and eutrophication. Bull Mar Sci 65:523-538

Gili JM, Coma R (1998) Benthic suspension feeders: their paramount role in littoral marine food webs. TREE 13:316-321

Glynn PW (1973) Ecology of a Caribbean coral reef. The Porites reef-flat biotope: Part II. Plankton community with evidence for depletion. Mar Biol 22:1-21 
Goldman JC, Dennet MR (2000) Growth of marine bacteria in batch culture under $\mathrm{C}$ and $\mathrm{N}$ limitation. Limnol Oceanogr 45:789-800

Goldman JC, Caron DA, Dennet MR (1987) Regulation of gross growth efficiency and ammonium regeneration in bacteria by substrate C:N ratio. Limnol Oceanogr 32:1239-1252

Grasshoff K, Kremling K, Ehrhardt M (1999) Methods of seawater analysis. Wiley-VCH, Weinheim

Hatcher BG (1983) The role of detritus in the metabolism and secondary production of coral reef ecosystems. In: Baker JT, Carter RM, Sammarco PW, Stark KP (eds) Proc Great Barrier Reef Conf. James Cook University Press, Townsville, p 317-325

Hatcher B (1997) Organic production and decomposition. In: Birkeland C (ed) Life and death of coral reefs. Chapman \& Hall, New York, p 140-174

Helder W, de Vries RTP (1979) An automatic phenol-hypochlorite method for determination of ammonia in sea- and brackish waters. Neth J Sea Res 13:154-160

Hinde R (1988) Symbiotic nutrition and nutrient limitation. Proc 6th Int Coral Reef Symp Townsville, Australia 1: 199-204

Johannes RE, Wiebe WJ, Crossland CJ (1983) Three patterns of nutrient flux in a coral reef community. Mar Ecol Prog Ser 12:131-136

Kinsey DW (1985) Metabolism, calcification and carbon production. I. System level studies. Proc 5th Int Coral Reef Cong Tahiti 4:505-526

Kirchman DL (1994) The uptake of inorganic nutrients by heterotrophic bacteria. Microb Ecol 28:255-271

Lee S, Fuhrman JA (1987) Relationships between biovolume and biomass of naturally derived marine bacterioplankton. Appl Environ Microbiol 53:1298-1303

Menzel DW, Vaccaro RF (1964) The measurement of dissolved organic and particulate carbon in seawater. Limnol Oceanogr 9:138-142

Moriarty DJW, Pollard PC, Hunt WG, Moriarty CM, Wassenberg TJ (1985a) Productivity of bacteria and microalgae and the effect of grazing by holothurians in sediments on a coral reef flat. Mar Biol 85:293-300

Moriarty DJW, Pollard PC, Hunt WG (1985b) Temporal and spatial variation in bacterial production in the water column over a coral reef. Mar Biol 85:285-292

Murphy J, Riley J (1962) A modified single method for determination of phosphate in natural water. Anal Chim Acta $27: 31-36$

Muscatine L, Falkowski PG, Dubinsky Z, Cook PA, Mc-

Editorial responsibility: Frede Thingstad,

Bergen, Norway
Closkey LR (1989) The effect of external nutrient resources on the population dynamics of zooxanthellae in a coral reef. Proc R Soc Lond B 236:311-324

Paul JH, DeFlaun MF, Jeffrey WH (1986) Elevated levels of microbial activity in the coral surface microlayer. Mar Ecol Prog Ser 33:29-40

Richman S, Loya Y, Slobodkin LR (1975) The rate of mucus production by corals and its assimilation by the coral reef copepod Acartia negligens. Limnol Oceanogr 20:918-923

Risk MJ, Müller HR (1983) Porewater in coral heads: evidence for nutrient regeneration. Limnol Oceanogr 28:1004-1008

Rivkin RB, Anderson MR (1997) Inorganic nutrient limitation of oceanic bacterioplankton. Limnol Oceanogr 42:730-740

Sharp JH (1997) Marine dissolved organic carbon: are older values correct? Mar Chem 56:256-277

Simon M, Azam F (1989) Protein content and protein synthesis rates of planktonic marine bacteria. Mar Ecol Prog Ser 51:201-213

Thomas FIM, Atkinson MJ (1997) Ammonium uptake of coral reefs: effects of water velocity and surface roughness on mass transfer. Limnol Oceanogr 42:81-88

Torréton JP (1999) Biomass, production and heterotrophic activity of bacterioplankton in the Great Astrolabe Reef lagoon (Fiji). Coral Reefs 18:43-53

Torréton JP, Pagès J, Dufour P, Cauwet G (1997) Bacterioplankton carbon growth yield and DOC turnover in some coral reef lagoons. Proc 8th Int Coral Reef Symp 1:947-952

van Duyl FC (1985) Atlas of the living reefs of Curaçao and Bonaire (Netherlands Antilles). Studies of the flora and fauna of Surinam and the Netherlands Antilles, Vol 117, Utrecht

Visser PM, Snelder E, Kop AJ, Boelen P, Buma AGJ, van Duyl FC (1999) Effects of UV radiation on DNA photodamage and production in bacterioplankton in the coastal Caribbean Sea. Aquat Microb Ecol 20:49-58

Wahbeh MI, Mahasneh AM (1988) Composition and bacterial utilization of mucus of corals from Aqaba (Red Sea), Jordan. Proc 6th Int Coral Reef Symp Townsville Australia 2:53-57

Wiebinga CJ (1999) Process studies of dissolved organic carbon and bacterioplankton in the ocean. PhD thesis, University of Groningen

Wilkinson L (1997) SYSTAT: the system for statistics. SYSTAT Inc, Evanston, IL

Yahel G, Post AF, Fabricius K, Vaulot DM, Vaulot D, Genin A (1998) Phytoplankton distribution and grazing near coral reefs. Limnol Oceanogr 43:551-563

Submitted: August 1, 2000; Accepted: January 12, 2001 Proofs received from author(s): March 13, 2001 